\title{
ANALISIS KENDALA YANG DIHADAPI NELAYAN DALAM MENINGKATKAN PRODUKSI IKAN LAUT DIPESISIR PANTAI AMPENAN KECAMATAN AMPENAN KOTA MATARAM
}

\author{
Rd Tuty Sariwulan*
}

\begin{abstract}
The aim study is to determine the constraints faced by fishermen in an attempt to increase marine fish production. The study was descriptive research using primary data collected from 20 respondents fishermen. Data collected were analyzed using tabulation or frequency analysis. The results showed that the constraints faced by fishermen obtained from a study of 20 respondents is as follows: equipment constraints as many as 14 respondents (70\%). Capital constraints 8 respondents (40\%) and the constraints of natural conditions a oranng respondents (5\%). While other constraints obtained the results of discussions with 20 people of respondents is the lack of constraint in writing regulations governing the location of fishing among anglers fishing with the fishermen penjaring so often the case a misunderstanding, then constraint relief boat model boat which does not comply with the condition of marine / aquatic fishing where the fishermen village of North Ampenan.
\end{abstract}

Keywords: fisherman, marine fish production, descriptive research

\section{PENDAHULUAN}

Kajian tentang wilayah pesisir pantai mendapat perhatian pada berbagai kalangan dewasa ini. Perhatian wilayah pesisir pantai ini disebabkan oleh berbagai faktor: Pertama, Indonesia adalah negara maritim dengan wilayah laut yang sangat luas terutama lagi dengan telah disepakatinya Konvensi Hukum Laut Internasional yang telah semakin memperluas wilayah laut Indonesia. Wilayah laut yang luas menyebabkan banyak kegiatan penduduk, khususnya mereka yang bermukim di wilayah pesisir pantai yang secara

\footnotetext{
Rd. Tuti Sariwulan. Dosen Fakultas Ekonomi Universitas Negeri Jakarta
}

\begin{abstract}
langsung atau tidak langsung berkaitan dengan pemanfaatan sumber daya laut (Basri Hassanuddin, 1999). Kedua, ada kesan pada sementara kalangan bahwa kebijaksanaan ekonomi dan pembangunan yang telah dilaksanakan selama tahun yang lalu umumnya diprioritaskan pada sektor pertanian yang banyak menyentuh dan menguntungkan wilayah pedalaman. Hal ini menyebabkan lambatnya perkembangan ekonomi para nelayan yang bermukim di wilayah pesisir pantai yang akan berimplikasi pada rendahnya pendapatan dan kemiskinan mereka.
\end{abstract}


Pada era otonomi daerah dewasa ini dimana pengelolaan pembangunan wilayah diserahkan kepada daerah masing-masing, oleh karena itu, pemerintah dan masyarakat harus dapat mengetahui potensi dan masalah-masalah yang dihadapi oleh masyarakat daerah itu, pengelolaan potensi daerah dan pemecahan kendala-kendala ini akan menyebabkan adanya kenaikan pendapat masyarakat.

Kecamatan Ampenan adalah salah satu dari 3 kecamatan yang ada di kota Mataram. Masyarakat pesisir pantai kecamatan Ampenan banyak yang berusaha di sector nelayan.. Kecamatan Ampenan dengan luas $23.58824 \mathrm{Km}^{2}$ terdiri dari 7 Kelurahan yang semuanya ini termasuk dataran rendah. Dari 7 kelurahan tersebut, 5 diantaranya merupakan daerah panitia, sedang sisanya bukan daerah pantai sebesar $28,3 \%$ dari luas wilayah (Kecamatan Ampenan dalam angka, 2000). Untuk lebih jelasnya diperlihatkan pada table berikut ini:

\section{Jumlah Keluraham di Kecamatan Ampenan dan Jumlah Pesisir Pantai} (tahun 2000)

\begin{tabular}{|c|l|c|c|c|}
\hline No. & Kelurahan & Pantai & Bukan Pantai & Dataran Rendah \\
\hline 1. & Pagutan & - & 1 & 1 \\
2. & Karang Pule & 1 & - & 1 \\
3. & Tanjung Karang & 1 & - & 1 \\
4. & Ampenan Selatan & 1 & - & 1 \\
5. & Ampenan Tengah & 1 & - & 1 \\
6. & Pejeruk & - & 1 & 1 \\
7. & Ampenan Utara & 1 & - & 1 \\
\hline
\end{tabular}

Berdasarkan pada tabel di atas, jelas terlihat bahwa dari 7 kelurahan yang ada di kecamatan Ampenan terdapat 5 diantaranya merupakan wilayah pantai. Kondisi nelayan di daerah ini terutama di kelurahan Ampenan Utara, pada umumnya masih terbelakang yang tercermin dari kehidupan ekonomi maupun dari segi sosial termasuk kondisi pemukiman mereka.

\section{Pokok Permasalahan}

Apa yang menjadi kendala utama bagi para nelayan dalam usaha peningkatan pendapatan mereka?

\section{LANDASAN TEORI}

Pengertian wilayah dalam kaitan dengan wilayah pesisir dalam buku pedoman pengelolaan dan pengembangan wilayah pesisir pantai oleh Lembaga Oseanologi Nasional, bahwa Wilayah Pesisir adalah pertemuan (daerah pertemuan) antara darat dan laut; kearah darat wilayah pesisir meliputi bagian daratan baik kering maupun terendam air, masih dipengaruhi oleh sifat-sifat laut seperti pasang surut, angina laut dan perembesan air asin; sedang kearah laut wilayah pesisir mencangkup bagian laut dan yang 
Rd Tuti Sariwulan: Analisis Kendala Yang Dihadapi Nelayan Dalam Meningkatkn Produksi Ikan Laut Di Pesisir Pantai Ampenan Kecamatan Ampenan Kota Mataram

masih dipengaruhi oleh prose salami yang terjadi di darat.

Mubyarto (2003), perikanan adalah segala usaha penangkapan, budidaya ikan serta pengelolaan sampai pemasaran hasilnya. Sedangkan sumber perikanan adalah binatang dan tumbuh-tumbuhan yang hidup diperairan baik di darat maupun di laut.

Upaya-upaya untuk meningkatkan produksi perikanan dengan cara sebagai berikut:
a. ekstensifikasi areal daerah penangkapan
b. intensifikasi perikanan
c. diversifikasi pengolahan sumberdaya perikanan
d. rehabilitasi prasarana dan sarana perikanan
e. pemberian penyuluhan terhadap masyarakat nelayan tentang bagaimana pengelolalteknik penangkapan ikan yang baik

Pada umumnya kegiatan nelayan pada suatu desa pantai sangat dipengaruhi oleh musim. Sifat usaha musiman dan skala usaha yang kecil telah menyebabkan nelayan tidak mempunyai kemampuan untuk mengontrol baik produksi, maupun harga ikan yang dihasilkan. Dimana produksi ikan mempunyai banyak kelemahan antara lain adalah produksi sangat tergantung musim, cepat rusak, bersifat inelastic sehingga harga sukar dikontrol, disamping itu karena tidak adanya industri pengalengan ikan NTB dan terbatasnya sarana pendukung lanyard sehingga jika produksi tingg, maka harga akan turun dan sebaliknya.
Permasalahan pokok yang dihadapi oleh para nelayan pada desa pantai menurut survei di Sulawesi Selatan oleh Basri Hasanudin adalah sebagai berikut:
a. masalah kekurangan modal
b. masih kurang efektifnya peranan dari lembaga-lembaga desa yang ada.
c. masih kurangnya bantuan dan petunjuk-petunjuk teknis dalam rangka peningkatan produktifitas
d. wilayah pantai telah mengalami apa yang disebut area fishing dalam arti bahwa jumlah nelayan telah melampau luas wilayah penangkapan yang ada

\section{METODE PENELITIAN}

Penelitian ini menggunakan metode deskriptif dengan maksud untuk dapat mengetahui kendalakendala yang dihadapi oleh para nelayan dalam meningkatkan produksinya atau pendapatannya dan tingkat kemiskinan dari para nelayan. Penelitian ini dilaksanakan di wilayah pesisir pantai Ampenan Utara Kecamatan Ampenan Kota Mataram. Populasi dalam penelitian ini adalah nelayan di wilayah pesisir pantai Kelurahan Ampenan Utara sebanyak 200 orang nelayan. Jumlah sampel yang diambil dari populasi sebanyak $10 \%$ dari populasi. Metode analisis yang digunakan untuk mengetahui kendala-kendala apa saja yang sangat dirasakan oleh nelayan dalam usaha peningkatan produksi atau pendapatannya dilakukan analisa tabel frekwensi. 
HASIL PENELITIAN

\section{Peralatan yang digunakan oleh nelayan}

Sebagian besar responden yaitu $60 \%$ menggunakan alasan pancing untuk menangkap ikan dilaut dan $40 \%$ menggunakan peralatan pancing dan jarring. Semua responden dalam melaut menggunakan "jarring" tradisional yaitu ukuran relative kecil dengan dayung dan layar serta dengan 2 sampai 3 orang dalam satu jaring. Harga jarring untuk ukuran tersebut sekitar Rp. 2.500.000 sampai Rp. 3.500.000 dan dengan mesin sampan berkekuatan antara 10PK sampai $15 \mathrm{PK}$.

\section{Pendapatan Nelayan}

Pendapatan nelayan yang bersumber dari hasil penjualan ikan untuk sekali melaut adalah tidak menentu dan rata-rata dibawah Rp. 100.000 sekali melaut.

Umumnya responden atau 17 orang responden (85\%) dari 20 orang responden menyatakan pendapatan mereka tidak, sedangkan 3 orang responden lainnya(15\%) menyatakan bahwa pendapatan mereka sekali melaut dibawah Rp. 100.000 seperti yang diperlihatkan pada tabel berikut:

\begin{tabular}{|c|l|c|}
\multicolumn{3}{|c}{ Pendapatan Nelayan } \\
\hline No. & \multicolumn{1}{|c|}{ Jumlah (Rp) } & $\begin{array}{c}\text { Jml } \\
\text { Resp. }\end{array}$ \\
\hline 1. & tidak tentu & 17 \\
2. & dibawah Rp. 100.000 & 3 \\
\hline & JUMLAH & 20 \\
\hline
\end{tabular}

Sumber : Data primer yang diolah th 2005

Dalam melakukan aktivitas melaut atau menangkap ikan dilaut hanya dapat dilakukan beberapa kali saja dalam sebulan. Demikian para nelayan juga tidak melakukan kegiatan produktif lainnya selama didarat karena keterampilan dibidang lainnya tidak dimiliki oleh para nelayan, sehingga pendapatan mereka hanya diperoleh dari tangkapan ikan laut.

Adapun kisaran kelaut menangkap ikan dalam sebulan dari 20 orang responden diperlihatkan pada tabel berikut:

Nelayan Melaut Selama Sebulan

\begin{tabular}{|c|l|c|}
\hline No. & Jumlah (Rp) & Jml Resp. \\
\hline 1. & dibawah 10 & 1 \\
2. & $10-20$ & 18 \\
3. & $21-30$ & 1 \\
4. & Tidak tentu & - \\
\hline & JUMLAH & 20 \\
\hline
\end{tabular}

Sumber : Data Primer yang Diolah Tahun 2005

Berdasarkan tabel diatas diketahui bahwa para nelayan tidak melakukan aktivitas menangkap ikan secara penuh dalam sebulan. Dari 20 orang responden nelayan 1 orang responden melaut dibawah 10 kali dalam sebulan. 18 orang nelayan melaut $10-20$ kali dan 1 orang responden nelayan 21 - 30 kali kelaut dalam sebulan. Para nelayan kelaut dalam setahun hanya dapat dilakukan maksimal selama 6 bulan. Minimnya para nelayan kelaut tentu dipengaruhi oleh salah satu diantaranya adalah kesederhanaan peralatan, perahu serta iklim/cuaca.

Hal ini tentu akan berpengaruh terhadap rendahnya tingkat pendapatan mereka selama setahun, 
menyebabkan para nelayan tradisional ini tetap dalam keadaan miskin.

\section{Kendala-kendala Yang Dihadapi Nelayan}

Di wilayah pesisir pantai Kelurahan Ampenan Utara tersebar pemukiman para nelayan tradisional. Salah satu pemukiman masyarakat yang umumnya bermata pencaharian sebagai nelayan adalah lingkungan pondokprasi. Dalam melakukan pekerjaan sebagai nelayan., mereka umumnya menggunakan peralatan dan perahu yang cukup sederhana. Kesederhanaan inilah yang mebuat produktifitas hasil ikan tangkapan akan rendah. Hasil tangkapan yang rendah pada gilirannya akan berpengaruh terhadap tingkat pendapatan nelayan, baik nelayan mini purse, nelayan malam maupun pada nelayan tongkol.

Penggunaan peralatan dan perahu yang cukup sederhana dapat menyebabkan rutinitas kelaut menangkap ikan tidak dapat dilakukan karena terhambat oleh musim, terutama pada musim barat dengan hujan, angina disertai dengan ombakyang besar.

Selanjutnya dari hasil penelitian ditemukan 4 kendala yang dihadapi para nelayan adalah sebagai berikut:

1. kendala peralatan

Pada umumnya para nelayan

di Kelurahan Ampenan Utara menggunakan peralatan dan perahu yang dimiliki oleh para nelayan akan menghambat dalam usaha-usaha rutinitas kelaut dan rendahnya produktifitas hasil tangkapan ikan. Rendahnya produktifitas hasil tangkapan ikan ini berpengaruh terhadap rendahnya pendapatan para nelayan.

Dari penelitian diketahui bahwa dari 20 orang responden nelayan, semua menggunakan peralatan sederhana yaitu 15 orang responden (75\%) hanya menggunakan pancing dan 5 orang responden (25\%) yang menggunakan pancing dan jaring. Sedangkan perahu yang digunakan adalah merupakan perahu-perahu kecil dan ini harus sesuai dengan kondisi laut sebagai lokasi penangkapan ikan.

Selanjutnya, dari hasil penelitian melalui diskusi para nelayan dirumah Kepala Lingkungan ditemukan bahwa perahu nelayan yang digunakan oleh para nelayan dari bantuan Pemerintah yaitu perahu yang tidak sesuai dengan laut tempat penangkapan ikan.

2. kendala pemasaran ikan

pemasaran merupakan salah satu aspek yang penting dalam kelangsungan usaha dan peningkatan pendapatan. Kelancaran dan perluasan pemasaran hasil produksi ikan sangat penting bagi para nelayan. Mengingat sifat ikan laut mudah rusak dan tidak tahan lama, sehingga harus secepatnya dijual. Oleh sebab itu, dalam pemasaran ikan laut ini diperlukan teknik pemasaran dan teknologi yang tinggi. Hal ini sangat dibutuhkan mengingat bila produksi melimpah otomatis harga turun, 
bila permintan tetap dan tidak terjadi perluasan pasar. Perluasan pasar atau jangkauan pemasaran ini juga merupakan salah satu factor penting dalam pemasaran, mengingat sampai saat ini hasil tangkapan ikan para nelayan Kelurahan Ampenan, hanya dipasarkan di Pasar KebonReok Ampenan dan pasar yang ada dikota Mataram.

Kendala-kendala ini timbul disebabkan para nelayan umumnya tidak mempunyai fasilitas penyimpanan ikan yang memadai, sehingga harus dijual secepatnya agar tidak rusak atau busuk. Disamping itu para nelayan umumnya tidak memiliki alat transportasi/kendaraan pengangkut ikan yang dapat menjangkau pasar yang lebih luas.

Selanjutnya hasil penelitian dari 20 orang responden nelayan ditemukan bahwa 11 responden (55\%) mengalami kendala pemasaran dalam usahanya. Kendala lainnya yang ditemukan pada hasil diskusi antar tim peneliti dengan 20 orang nelayan diantaranya adalah:

a. Tidak adanya peraturanperaturan tertulis tentang lokasi tempat penangkapan ikan dilaut antara nelayan yang menggunakan pancing dan nelayan yang menggunakan jarring., hasil tersebut menyebakan kadang-kadang terjadi kesalahpahaman diantara nelayan. b. Bantuan perahu dari investor yang terkait, tidak sesuai yang diharapkan oleh para nelayan yaitu model perahu tidak sesuai dengan kondisi laut yang dilalui. Hal ini dapat menyebabkan terjadi kendala-kendala dalam pengoperasiannya, disamping kendala perahu juga ada kendala peralatan alat penangkapan ikan.

3. kendala modal

Dalam setiap usaha, masalah pemodalan memegang peranan penting baik yang berwujud uang atau barang, sehingga sulit dipisahkan antara modal dengan dunia usaha.

Aspek permodalan dalam penelitian ini merupakan kendala ketiga setelah peralatan dan pemasaran. Kendala modal yang dihadapi oleh nelayan adalah kendala modal berupa uang yang dapat digunakan sebagai biaya operasional untuk kelaut menangkap ikan dan biaya-biaya operasional lainnya. Masalah permodalan ini, sangat terasa bagi nelayan jika mereka mempersiapkan bekal dilaut, peralatan dan sarana/prasaranalainnya yang diperlukan untuk kelaut menangkap ikan.

Selanjutnya, dari hasil penelitian terhadap 20 orang responden nelayan ditemukan bahwa 8 orang responden mengalami kendala-kendala modal berupa uang. Adapun upaya yang dilakukan oleh para 
nelayan untuk mengatasi kendala modal dilakukan dengan meminjam dari teman, dan menabung. Hasil penelitian dari 20 orang responden nelayan ditemukan 10 orang responden $(50 \%)$ mengatasi kendala modal dengan cara meminjam dari teman, 9 orang responden $(45 \%)$ tidak berupaya/pasrah dan hanya 1 orang responden (5\%) mengatasi kendala modal dengan cara menabung.

4. kendala kondisi alam

pada umumnya nelayan di Kelurahan Ampenan Utara melakukan penangkapan ikan terbatas di daerah Pantai Pulau Lombok dengan kapasitas tanngkapan yang rendah. Mereka pada umumnya bermukim di daerah pesisir pantai. Pekerjaan sebagai nelayan merupakan pekerjaan turun menurun dan mengandalkan peralatan yang sederhana dan perahu kecil dalam usahanya menangkap ikan. Dalam melakukan menangkap ikan dilaut hamper semua responden tidak mengalami kendala kondisi alam pada waktu cuaca baik kecuali pada musim barat (musim paceklik) dimana angina kencang, hujan dan ombak besar dapat terjadi sehingga para nelayan secara otomatis tidak turun kelaut.

Dari hasil penelitian pada 20 orang responden nelayan, diketahui bahwa hanya 1 orang responden (5\%) merasakan kondisi alam. Sedikitnya responden mengalami kondisi alam selain musim barat karena para nelayan hanya melakuakan penangkapan ikan tidak jauh dari pantai meskipun dengan peralatan yang sederhana dan perahu kecil.

\section{KESIMPULAN}

1. Pada umumnya nelayan di Kelurahan Ampenan Utara adalah nelayan tradisional dengan menggunakan peralatan menangkap ikan yang sederhana yaitu pancing 15 orang (75\%) dan pancing \& jarring 5 orang (25\%) dari 20 orang responden nelayan.

2. Kendala-kendala yang dihadapi oleh para nelayan dalam usahanya secara berturut-turut adalah kendala peralatan 14 orang $(70 \%)$, kendala pemasaran 11 orang $(55 \%)$, kendala modal 8 orang responden (40\%) dan kendala kondisi alam 1 orang responden $(5 \%)$ dari 20 orang responden nelayan yang teliti.

3. Dalam menghadapi kendala diatas, para nelayan mengatasi dengan cara: meminjam dari teman sebanyak 10 orang $(50 \%)$, menabung 1 orang (5\%), sedangkan 9 orang responden (45\%) tidak berupaya /pasrah dari 20 orang responden yang teliti.

4. Kendala yang ditemukan dari hasil diskusi dengan 20 orang responden nelayan adalah kendala adanya kesalahpahaman antara nelayan, karena tidak adanya peraturan secar tertulis 
mengenai lokasi penangkapan ikan. Disamping itu, kendala bantuan perahu kepada nelayan, modelnya tidak sesuai dengan kondisi laut alur penangkapan ikan para nelayan yang mendapat bantuan.

\section{SARAN}

1. Agar para nelayan dapat meningkatkan produktifitas dan jangkauan penangkapan ikan, disarankan kepada Pemerintah dan Swasta untuk memberika bantuan modal dengan pengembalian bunga lunak atau bagi hasil.

2. Bila Pemerintah ataupun Swasta memberikan bantuan kepada para nelayan, disarankan agar para nelayan dilibatkan didalam penentuan model perahu agar modelnya sesuai dengan kondisi laut atau tempat penangkapan ikan.

3. Disarankan kepada para nelayan agar membentuk koperasi nelayan agar masalah permodalan dan pembinaan lebih mudah dilaksanakan.

\section{DAFTAR PUSTAKA}

Departemen Tenaga Kerja RI 1999, Pelatihan Dasar Kewirausahaan, Self Employment Programmes for Training Institution, Local Enterprise Development Agency. Kerjasama Departemen RI dengan ILO dan UNDP.
Djamaluddin, MM. 2002, Penggunaan Model Input Output dalam Perencanaan Pembangunan Sulawesi Tenggara, Universitas Hasanuddin Makasar.

Jhon G. 2000. Pengantar Perencanaan Regional Terjemahan Paul Sitohang, Lembaga Penerbit Fakultas Ekonomi Universitas Negeri Jakarta.

Lincoln Arsyad, 1998. Studi Pengembangan Desa Pantai di Propinsi Riau, Yogyakarta

Mubyarto dkk, 1994. Nelayan dan Kemiskinan Studi Ekonomi Antropologi di dua Desa Pantai, Penerbit CV. Rajawali, Jakarta.

Patingari, Rasyid,2002. Analisis Perkembangan Ekonomi Pedesaan wilayah Pesisir Teluk Mandar, Universitas Hasanuddin Makasar.

Tim B3PK UGM, 2000. Studi Pengembangan Desa Pantai Propinsi Riau, Yogyakarta.

Zulkarnaen, 2002. Peranan Dana IDT Dalam Meningkatkan Pendapatan Masyarakat Miskin Anggota Pokmas Di Kodya Mataram (Kasus Desa Sayang-sayang Kecamatan Ampenan) Fakultas Ekonomi UNRAM, Mataram. 